\title{
"Poets had moved in this country once": John Mulgan and Romantic Poetry
}

\author{
HEIDI THOMSON
}

\begin{abstract}
In Part Two of Man Alone John Mulgan describes a farm in the fen country of Northamptonshire: "Poets had moved in this country once, Cowper and John Clare, but few poets moved there now." The significance of the reference to these two poets, both of whom had been institutionalized for insanity and both of whom found solace in working the land, cannot be underestimated for Mulgan's emotional characterization of the main character, Johnson. This essay focuses on some of Mulgan's references to English Romantic poetry (William Cowper, John Clare, and Lord Byron in particular) and how these references evoke his melancholy frame of mind.
\end{abstract}

The one-sentence paragraph which prompted this short essay occurs towards the end of John Mulgan's Man Alone, when Johnson is working on a farm in Northamptonshire in England. It reads like this: "Poets had moved in this country once, Cowper and John Clare, but few poets moved there now." "The sentence is preceded by the description of the Great North Road which ran across from the farm "with traffic thundering along it night and day": "No horses there, but heavy trucks and motor coaches, and the smart cars of new England, tearing through the country-side. There was a military aerodrome two miles to the north and all day planes sang overhead like fighting birds." "It is followed by a paragraph about the other farm labourers, "kind, solid, well meaning fellows" who were all settled in a way that Johnson was not: "He worked with them and talked with them. He liked them, was not worried by them, but he made them uneasy. He could feel this. He was older than they were, he was older than old Joe. He was more worn, more travelled, though he never talked of this. He did not belong there and they knew it." 3 The sudden reference, wedged in between the traffic of cars and planes along and above the Great North Road and the fellows on the farm, to these two poets is surprising. I believe that the association of William Cowper and John Clare with this location mattered greatly to Mulgan, and while I had originally intended to focus on the characterization of Johnson in Man Alone in this paper I will restrict myself to a few points about why Mulgan may have had a particular interest in poets, and how poetry mattered in his short life.

Much remains to be done about John Mulgan's ambivalent relationship with poetry, or more precisely the "poetical." As a writer and human being he distanced himself from the "poetical," aiming for economic precision in his own writing and detailed, yet unsentimental, clarity in his communications. His letters, incredibly fluent and well written from a young age, are exhaustively conclusive journal accounts of experiences and events, admitting only rare glimpses of emotional states. The sheer amount of detail and the liveliness of the evocations makes one forget how little he is actually giving away, particularly because Mulgan was very responsive to other people's requests for support or advice. I was struck by Mulgan's letters to his father, a prolific writer himself whose Georgian tastes in poetry differed markedly from his son's. In a variation of Wordsworth's "the child is the father of the man," John Mulgan sounds like a father to his father in his letters, reassuring, guiding, editing and offering advice on his writing, wielding, however mildly and considerately, a senior authority which seemed to preempt any vulnerability or disclosure of his own fears or anxieties.

Part II of Journey to Oxford elaborates on Mulgan's ideas about poetry and already in the first paragraph we get a reference to John Clare: "In New Zealand it is very difficult to read 
English poetry unless one has come from England or has visited it. I remember trying to be enthusiastic over John Clare beside a sea that was as blue as old wine, beneath trees that were as green as deep ice, and the falsity of turning to another man's country was hateful." 4 While reading English poetry out of its British context did not make sense for Mulgan, writing poetry in New Zealand was equally challenging, with the English influence turning the result into "a kind of chill pastoral and the lines of the hills which are as sharp and clear as a charcoal drawing became blurred and picturesque." "We should have given up writing poetry," Mulgan continues, "and made things with our hand or else told each other simple stories in prose: but there was some curse on us." 6

Yet, of course, Mulgan himself went to England in 1933 and never returned to New Zealand. Onboard the ship that took him to England he embarked on an ambitious schedule of poetry reading in preparation for his course of study at Oxford University (he was arriving late in the term): Chaucer, Donne, but primarily the Romantics: Blake, Wordsworth, Byron, Keats, Shelley, Burns. A couple of days out of England he wrote to his parents: "It was interesting reading all the Romantics in quantity together-I wished that I had a Coleridge out. Wordsworth I found as good as I had expected, Byron was my discovery, \& Keats was very pleasant but I thought Shelley perfectly damnable." " Byron, whom he read first, suited himself "and the blue Pacific." "Both Mulgan and Byron loved the sea, it suited them temperamentally as men whose charming sociability disguised the fundamental loneliness of depressive mind. Byron's poetry and Mulgan's prose take great note of the sea, ships, and voyages, particularly at the bittersweet moment of departure, a favourite topos in both writers' work with its connotations of promise and loss. Much more could be made of Byron's and Mulgan's parallel sensibilities. Both craved action and they shared a deep affection for Greece.

At Merton College Mulgan encountered more Romantic poetry through Edmund Blunden, his academic tutor, and H. W. Garrod, librarian and editor of, among others, Coleridge and Keats. Blunden became a friend and a role model, and Mulgan based his own poem "Memory," published in Best New Zealand Poems of 1934, on Undertones of War, Blunden's own 1928 account of his World War One experiences. ${ }^{9}$ Blunden's memoir struck a chord with Mulgan who advised his parents to read it too. ${ }^{10}$ More importantly, it was through Blunden that Mulgan would have learnt to appreciate John Clare's poetry, not for its pastoral vision of merry England, but for its unflinching record of what it means to be 'man alone.'

Briefly: John Clare (1793-1864) was a farm labourer, naturalist and poet who wrote about what he called his "knowledge": the landscape of Helpston in Northamptonshire, its birds and inhabitants. It's not entirely clear what he suffered from, but his health, both physical and mental, was fragile. For a while in the 1820s he was celebrated in London circles as a prodigy, a peasant poet, but by the time he was in his thirties he had collapsed, ending up in Dr Matthew Allen's asylum in Epping Forest. At one stage he walked from High Beach back to Helpston along the Great North Road (according to Google Maps almost 84 miles, 27 hours of walking), an experience he recorded in "Journey out of Essex," a trip not too unlike the one Mulgan sends Johnson on in Man Alone. Even though Clare was married to Martha Turner he also fancied himself married to his first love Mary Joyce, and "thought that he was kept in a madhouse as a punishment for bigamy." 11 He also imagined himself to be Robert Burns, Byron, Nelson and the prize-fighter Ben Caunt. He ended up living at the Northampton General Lunatic Asylum until his death in 1864, and was given "freedom to roam around Northampton."12

Blunden himself had taken Arthur Symons's 1908 edition of Poems by John Clare to the war, one of the few pocket books he took with him. As we find out in Undertones of War, Blunden realized that he had lost the book while attending "gas school" (as he called it) in the Nord-Pas-de-Calais village Hinges. ${ }^{13}$ Almost immediately upon his return from the war Blunden reclaimed the Clare he had lost: by 1920 he had produced John Clare: Poems Chiefly from Manuscript in two volumes. Blunden's edition marked the beginning of a new perspective 
on John Clare, with far more emphasis on the asylum poems, a perspective no doubt influenced by the trauma of the trenches and the way in which Clare's poetry would have given a voice to the tragic bewilderment and the alienation of the returned soldiers. In addition, Blunden published The Waggoner, a collection of his own poetry, in the same year. ${ }^{14}$ One of the poems in that collection, "Clare's Ghost," evokes Blunden's understanding of Clare's poetic identity in the light of his own experience of no man's land where "a multitude more outpouring / Die foiled in the endeavour." 15

And a stranger stands with me here in the glow

Chinked through the door, and marks

The sparks

Perish in whirlpool wind, and if I go

To the delta of cypress, where the glebe gate cries,

I see him there, with his streaming hair

And his eyes

Piercing beyond our human firmament,

Lit with a burning deathless discontent. ${ }^{16}$

The evocation of the unflinching focus of Clare's ghost in the face of mass destruction rewrites the idea of the pastoral which had traditionally been associated with Clare. As Stephanie Weiner writes: 'In 'Clare's Ghost' and in many of the poems Blunden selects for Poems Chiefly from Manuscript, Clare is disillusioned, preoccupied with his own exile and fall from innocence, and outraged by the indecency and violence of human civilization. Whereas previous commentators, including Symons, had tended to emphasize the harmony and pastoral calm of Clare's portrait of nature and village life and to interpret his later poems in terms of 'gentle hallucination' and an increase of imaginative license, Blunden draws attention to poems in which 'Clare's mind . . . dwell[s] on loneliness and suffering — and resistance."'17

Blunden's post World War 1 version of Clare, a man alienated from himself, driven to madness, helplessly angry about the agricultural enclosures and their transformative effect on the landscape and its people, the alienation of people from each other, in the wake of the Napoleonic wars with France, became Mulgan's Clare during the depression of the 1930s and the premonition of more war. The other poet of the sentence in Man Alone, William Cowper (1731-1800), shared with Clare recurrent bouts of depression and insanity which took the form of religious mania, with symptoms which were also alleviated, up to a point, by physical activity outdoors, by gardening. He attempted suicide on a number of occasions and suffered greatly "under the obsession that he was damned." 18 These last words are from Mulgan and Davin's Introduction to English Literature, a reworked version of Emile Legouis' 1934 A Short History of English Literature and published posthumously in 1947. Both Clare and Cowper, depressives with a flair for epistolary brilliance (both left letters which have become masterpieces in their own right), found comfort in physical labour and in the landscape of Northamptonshire.

While the poets may have disappeared from the Northamptonshire landscape in the 1930s, Johnson shared some characteristics with them in his loneliness and uprootedness. The Johnson who works at the farm in Peterborough has gone through a series of identities:

He had changed his name by then and changed himself a good deal from the Johnson of other days. He was not the man who had grown up in England by the Chiltern hills, nor the man who slight, callow, afraid, had served with the light infantry in mud and 
cold and dirt and death, fighting a war, to him incomprehensible, to the world unnecessary. He was not that Johnson who had liked sun and free country and beer and small race meetings, not that man living free, not caring where he worked, what he did. Nor that other man knowing hardship and fear of the future and death by poverty as old friends. Nor that last man hunted, in a life over which he had no control. ${ }^{19}$

Yet, in contrast with Clare and Cowper, Mulgan, at this late point in the novel, assigned a resilient core of "endurance" to Johnson which pointed to what Vincent O'Sullivan calls a "more inclusive humanity." ${ }^{20}$ By volunteering to fight in Spain Johnson finds meaning in community: "I've only felt like this sometimes,' he said, 'going somewhere with people I liked, doing something together. It's a fine feeling. Most of the time a man spends too much alone." "21

Mulgan himself ended up more like Clare and Cowper, unable to resist the darkness which pulled him in, but in the light of what he achieved in Greece in particular, his effort was heroic to say the least. It was, ironically, in the Peterborough landscape that he spent some of the self-professed happiest times of his life, doing what he loved best, working on the land. In July 1934 Mulgan went up to Sacrewell, "650 acres, two farms joined together," run by a gentleman farmer called Abbott, where he worked 8-9 hours, very hard, hay making, picking potatoes. ${ }^{22} \mathrm{He}$ loved it and wrote to his parents that he lived with the "foreman in the other house, where I am well looked after by his wife \& daughter": "I am very well \& happy." "23 The word "happy" recurs time and again in the letters home during this time - it was a somewhat escapist kind of happiness founded on the physical exhaustion of manual labour, with enough time for some intellectual engagement in the evening but not enough time for brooding: "I have been on the land a month now \& thoroughly enjoyed it all. Work of this kind if it solves no intellectual problems \& worries at least doesn't present any. Today, I have worked hard, 8-9 hours, pitchforking stable manure, prosaic but nice to think of it going on the land \& making the grass grow. It has been hard work lifting \& throwing but I feel fine with it \& I think can back myself to hold down a man's job anytime I have to." ${ }^{24}$ In 1937 Mulgan and his wife Gabrielle went on their honeymoon to Brittany, but the next year, in June 1938, he went back, by himself, to Sacrewell while Gabrielle went on a walking tour with a friend in Cornwall. To his parents he wrote that he "enjoyed the company of the men here again. They have a simple honesty \& humour that people lose in towns." 25

The war started in September 1939. The memory of working on the land sustained Mulgan up to a point. Bristling with impatience about his military superiors he wrote to Gabrielle from Southampton in May 1940: "I'd love another week just to wear old clothes and garden in the sun. This brigadier is getting me down more than the Germans." 26 With death on his mind (and it's hard to know whether it's the awareness of the war or his own depressive thoughts guiding him here) he advised her in August 1940 that he wanted their son Richard "to be a farmer or a garage hand":

He can read and write then if he wants to for he will have something to write about and he will be as happy or happier than I have been, I know, he will not be worried about ambition or a career and politics and the state of the world will be real things to him and not discussions in undergraduate debating clubs. Will you remember this if you ever have to leave him to someone else to educate? ${ }^{27}$

At a distance from Gabrielle and the rest of his family, Mulgan articulated more directly how he thought about himself, expressed more clearly that he was "not happy yet, not clear in myself as I should want to be, not satisfied and fulfilled." ${ }^{28}$ A month later, having realized probably how disconcerting this must have sounded, he reassures Gabrielle: "I'm really very happy, 
perhaps age or maturity, since I was writing you last about the melancholy sadness of my life, been thinking and realising how more content and self-contained I am" (1 June 1941). ${ }^{29}$ Yet, it must have been increasingly hard to keep the melancholy at bay. Mulgan's favourite evening reading onboard the ship to England had been Boswell, and it seems apt that Boswell's description of Samuel Johnson's mind also applied to his: "His mind resembled the vast amphitheatre, the Colisæum at Rome. In the centre stood his judgement, which like a mighty gladiator, combated those apprehensions that, like the wild beasts of the Arena, were all around in cells, ready to be let out upon him. After a conflict, he drives them back into their dens; but not killing them, they were still assailing him." 30

Unable to give Gabrielle the reassurance that she needed, he admitted to her in August 1943 that his life had not been what he feels he was made for: "I can only be now as I am. . . . I have given up trying to do badly things that I wasn't meant to do . . . I don't think it's ever going to be any settled domestic peace living with me, everything I believe seems to react against it . . . . I think I was given a body and a mentality-if you could dignify it by that name - which was meant for working on a farm or sailing a boat — and instead I've been crouching in houses all my life giving a bad imitation of a lover of the printed word." 31 Mulgan took his own life on Anzac Day 1945, choosing the day which commemorates New Zealanders killed in the war. The final line in the Epilogue of Man Alone states that "[ $\mathrm{t}]$ here are some men, this fellow said, you can't kill." 32 But this war, Mulgan's date suggests, finally killed him. He left a farewell letter for Zoe Tsiminaki, whom he loved and who had been his assistant in Athens doing the job which might well have finished him (or anybody) off: figuring out compensation for those who had been victimized by the horrors of the wars in Greece. He addressed her as "Zoe mou," which means both "My Zoe" and "My life." I can't help but read that letter with that pun in mind. Moreover, Mulgan was thinking of poetry in these final hours, of Byron's poetry, his 1810 poem, "Maid of Athens, Ere We Part," which has this line for its

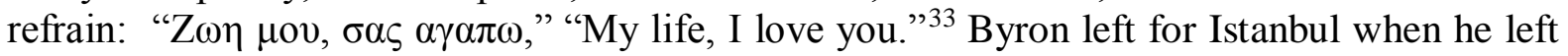

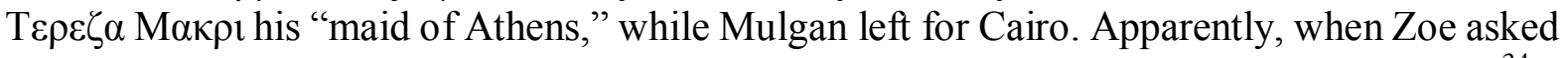
him to keep in touch, Mulgan had replied: "You will always know where I am from now."34

\footnotetext{
${ }^{1}$ John Mulgan, Man Alone (Auckland: Penguin Books, 1990), 190.

${ }^{2}$ Ibid.

${ }^{3}$ Ibid., 191.

${ }^{4}$ John Mulgan, Journey to Oxford, ed. Peter Whiteford (Wellington: Victoria University Press, 2011), 11.

${ }^{5}$ Ibid., 12.

${ }^{6}$ Ibid.

${ }^{7}$ John Mulgan, A Good Mail: Letters of John Mulgan, ed. Peter Whiteford (Wellington: Victoria University Press, 2011), 23.

${ }^{8}$ Ibid., 18.

${ }^{9}$ Ibid., 63. Vincent O'Sullivan, Long Journey to the Border: A Life of John Mulgan (Auckland:

Penguin Books, 2003), 114-15.

${ }^{10}$ Mulgan, Good Mail, 63.

${ }^{11}$ Eric H. Robinson, "Clare, John (1793-1864)," Oxford Dictionary of National Biography, accessed August 6, 2015, http://www.oxforddnb.com/view/article/5441 .

${ }^{12}$ Ibid.

${ }^{13}$ Edmund Blunden, Undertones of War (London: Cobden-Anderson, 1928), 30-31.

${ }^{14}$ Stephanie Kuduk Weiner, Clare's Lyric: John Clare and Three Modern Poets (Oxford: Oxford University Press, 2014), 143.

${ }^{15}$ Edmund Blunden, The Waggoner and Other Poems (London: Sidgwick and Jackson, 1920), 56.

${ }^{16}$ Ibid., 58 .
} 
${ }^{17}$ Weiner, Clare's Lyric, 146.

${ }^{18}$ John Mulgan and D. M. Davin, An Introduction to English Literature (Oxford: Clarendon Press, 1947), 88.

${ }^{19}$ Mulgan, Man Alone, 189.

${ }^{20}$ O'Sullivan, Long Journey, 195.

${ }^{21}$ Mulgan, Man Alone, 205.

${ }^{22}$ Mulgan, Good Mail, 48.

${ }^{23}$ Ibid., 49.

${ }^{24}$ Ibid., 51.

${ }^{25}$ Ibid., 138.

${ }^{26}$ Ibid., 167.

${ }^{27}$ Ibid., 177.

${ }^{28}$ Ibid., 197.

${ }^{29}$ Ibid., 198.

${ }^{30}$ James Boswell, The life of Samuel Johnson, LL.D. comprehending an account of his studies and numerous works, in Chronological order; a series of his epistolary correspondence and conversations with many eminent persons; and various original pieces of his composition, never before published. The whole exhibiting a view of literature and literary men in Great-Britain, for near half a century, during which he flourished. In two volumes, Eighteenth-Century Collections Online. Accessed August 18, 2015.

http://find.galegroup.com.helicon.vuw.ac.nz/ecco/infomark.do?\&source=gale\&prodId=ECCO\&userG

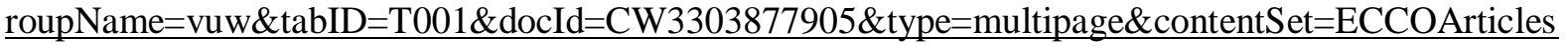
\&version $=1.0 \&$ docLevel=FASCIMILE.

${ }^{31}$ Mulgan, Good Mail, 259.

${ }^{32}$ Mulgan, Man Alone, 207.

${ }^{33}$ The Poetical Works of Lord Byron (London: Oxford University Press, 1957), 60.

${ }^{34}$ O'Sullivan, Long Journey, 334. 